\title{
Slawomir Drelich*
}

\section{W NIEWOLI BRUDU I CZYSTOŚCI}

Recenzja książki: Georges Vigarello, Historia czystości i brudu. Higiena ciała od czasów średniowiecza, przeł. B. Szwarcman-Czarnota, Wydawnictwo Aletheia, Warszawa 2012.

Historia czystości i brudu Georgesa Vigarella to swoiste dzieje ograniczeń, które kultura nakładała na człowieka i jego ciało, to opowieść o tym, jak człowiek dawał się uwieść wodzie i tysiącom innych technik oraz metod usuwania brudu, to wreszcie historia europejskiego rozwoju cywilizacyjnego, lecz widziana przez pryzmat codziennych zabiegów w zakresie higieny osobistej. Autor książki od samego początku daje się poznać jako zauroczony pisarstwem i pomysłami Michela Foucaulta, w szczególności zaś tymi, które skupiały się na okiełznaniu cielesności, zapanowaniu nad ludzkim korpusem i ukształtowaniu go wedle zdefiniowanego wzorca. Foucaultowskie Historia szaleństwa w dobie klasycyzmu (Foucault 1987), Historia seksualności (Foucault 2010) oraz Nadzorować i karać: narodziny więzienia (Foucault 2009) wpisują się w refleksję nad faktycznym zniewoleniem człowieka przez: po pierwsze - zarysowanie granicy między zdrowiem i chorobą oraz normalnością i nienormalnością; po drugie - władcze zdefiniowanie prawidłowych form realizacji potrzeb seksualnych i dopuszczalnych sposobów ich ewentualnej kompensacji; po trzecie - określenie wielu zabiegów o charakterze resocjalizacyjnym stosowanych wobec jednostek nonkonformistycznych. Natomiast Historia czystości i brudu to głos w tej samej dyskusji, jednak tutaj zniewolenie człowieka staje się faktem na skutek rozbudowania infrastruktury osobowo-higienicznej, czyli zdefiniowania już nie wyłącznie swoistej technologiki czystości, ale wszystkiego, co w jakikolwiek sposób dotyczy troski człowieka o swój wygląd zewnętrzny, możliwości fizyczne i ogólną sprawność, zdrowie oraz estetykę ciała. Georges Vigarello pokazuje się nam nie jako zwyczajny historyk czy socjolog, ale jako historyk społeczny, dla którego problem brudu i czystości stanowi wskaźnik ważnych zmian społecznych, politycznych i gospodarczych. Widzimy tutaj dowód tezy postawionej przez Foucaulta, że „to nie życie jest podporządkowane normom,

\footnotetext{
* UMK - Toruń; s.drelich@wp.pl
} 
które miałyby na nie oddziaływać z zewnątrz; to raczej normy są wytwarzane, w sposób całkowicie immanentny, w ruchu życia" (Macherey 2011: 117).

Rozważania swoje G. Vigarello zaczyna od wskazania tego, co zauważył już wcześniej Walzer, a mianowicie, że w czasach przednowożytnych - w przeciwieństwie do troski o duszę ludzką i zbawienie - „troskę o ciała, dla odmiany, powszechnie uznawano za mniej oczywistą i mniej pewną, a więc i mniej istotną, pozostawiano ją więc w prywatnych rękach" (Walzer 2012: 38). Refleksje nad definiowaniem brudu oraz społecznie akceptowalnymi sposobami troski o czystość nieustannie powracają do postrzegania wody przez ludzi różnych epok (czytamy o tym w części pierwszej pt. Od wody odświętnej do wody budzqcej niepokój). Ten życiodajny - jak dziś udowadniają naukowcy - żywioł był traktowany jako medium przenoszące niebezpieczne miazmaty (skutkowało to przyjmowaniem rozstrzygnięć legislacyjnych, mających na celu ograniczanie bądź wręcz likwidację publicznych kąpielisk), jako przyczyna odsłaniania por skórnych, przez które wdzierać się miały zarazki wszelkiej maści (skłaniano tym samym do uprawiania „suchej toalety”, wycierania materiałami i wcierania substancji zapachowych), jako jeden z warunków dobrej zabawy i relaksu (czasem utożsamianych ze sprośnością, rozpustą, rozbuchaną erotyzacją, rozwiązłością, co także niejednokrotnie skutkowało delegalizowaniem publicznych łaźni pod hasłem ochrony moralności i porządku publicznego). Wodę postrzegano również jako nosicielkę tajemnej energii pobudzającej i dynamizującej ludzkie ciała, w szczególności jeśli użyć zimnej wody, nie zaś ciepłej, która rozleniwia (liczą się więc w pierwszej kolejności rzekome jej walory zdrowotne, a dopiero w drugiej kolejności - myjące), jako uniwersalne lekarstwo minimalizujące spadek liczebności populacji, gwarantujące zdrowie społeczne i zapewniające czyste powietrze (pojawiają się kampanie społeczne promujące kąpiele i mycie, uruchamiane są łaźnie publiczne, a nowe urządzenia służące do higieny - m.in. intymnej - trafiają już nie tylko do domów zamożnych arystokratów).

Georges Vigarello pokazuje, że sposób postrzegania wody i interpretowania jej właściwości w sposób zdecydowany konotował ludzką codzienność i zwyczaje związane nie tylko z tym, co w XIX wieku nazwano higieną osobistą. Widzimy tutaj pewną historyczną ciągłość, jednak - zgodnie z interpretacjami Foucaulta - każde z postrzeżeń wody jesteśmy w stanie ująć w odrębne pole epistemologiczne charakterystyczne dla danej epoki, warunkujące wiele procesów dyskursywnych i niedyskursywnych. Autor postępuje zgodnie z wskazaniami z Archeologii wiedzy, iż ,trzeba oczywiście odrzucić w samych analizach historycznych stosowanie pojęcia nieciągłości, określanie poziomów i granic, opisy swoistych serii, uwydatnianie układów różnic" (Foucault 1977: 39). Spojrzenie z perspektywy ciągłości i braku radykalnych, jednoznacznych linii demarkacyjnych, to niewątpliwie bardzo atrakcyjny sposób uprawiania historii i - trzeba mocno podkreślić - G. Vigarello doskonale temu zadaniu sprostał. Tym bardziej, że zestawia on postrzeganie wody, bielizny i perfum z zagadnieniami hierarchii społecznej, zamożności i tego, co współcześnie można by określić mianem kapitału społecznego i kulturowego (część druga pt. Bielizna, która myje oraz część trzecia pt. Od wody, która wnika w ciało, do wody, która je wzmacnia). Dostęp do tych trzech dóbr - od momentu upowszechnienia się traktowania ich jako społecznie pożądanych i życiodajnych, czyli mniej więcej od ok. XIX wieku - stanowił o statusie społecznym, ale również o przywiązaniu do moralności. Czystość stała się więc nie tylko przejawem troski 
o zdrowie czy też potwierdzeniem życiowego powodzenia, ale zarazem świadectwem moralności (część czwarta: Woda, która chroni). Swoista socjalizacja do czystości rozpoczynać się miała w szkole podstawowej, gdzie schludny wygląd był w sposób wyrazisty promowany. Świadczą o tym: podręczniki szkolne, literatura filantropijna, dydaktyczne kazania - jednym słowem: propaganda czystości! Georges Vigarello charakteryzuje zabiegi władz państwowych o podniesienie poziomu edukacji w zakresie higieny i troski o zdrowie pod hasłem dążenia do zagwarantowania ładu moralnego. Widać poszerzające się spektrum panowania „czystościowego mainstreamu”. Widać, jak macki lewiatana ogarniają kolejne sfery życia człowieka, tworząc nowe formuły normatywne, w które ujęci mają być nowi obywatele. Czy nie mamy tutaj do czynienia ze składową opisywanego przez Foucaulta w Nadzorować i karać procesu ujarzmiania człowieka, przez co uczyni się go posłuszniejszym i łatwiej kontrolowanym przez instytucje państwa? Autor Historii czystości i brudu nie odwołuje się wprost do autora Historii szaleństwa, jednak skojarzenia takie nasuwają się natychmiastowo i trudno zapomnieć o nich podczas właściwie całej lektury.

Georges Vigarello - wedle wskazań Foucaulta - dokonuje „zakwestionowania jakichkolwiek teleologii i totalizacji” (Foucault 1977: 41). Okazuje się, że i brud zmienia swoje znaczenie, że nie jest tym samym, czym był kiedyś. Dopóki utożsamiany był z odorem, czyli nieprzyjemnym zapachem, dopóty walka z nim była stosunkowo prosta, choć wymagała rzecz jasna dostępu do odpowiednich preparatów, urządzeń czy roślin, które pozwalały ów odór wyeliminować. Brud miazmat nie wdarł się do organizmu, jeśli zabezpieczyliśmy wszystkie możliwe „wejścia”. Ciało hartowane niczym stal również nabywało „wyuczonej” odporności: z jednej strony - co już wspominano - przez kąpiele w zimnej wodzie, z drugiej zaś - przez surowość obyczajową, której symbolem miała być właśnie zimna woda. Georges Vigarello przywołuje w tym miejscu wiele nowożytnych odwołań do źródeł antycznych walka z brudem i gnuśnością to nic innego jak powrót do starych, dobrych ideałów prostoty, ascezy i skromności, przeciwstawianych coraz częściej nowożytnej rozwiązłości, zepsuciu i dekadencji. Pojawia się tutaj i Rousseau, dla którego główną odpowiedzialną za wszelkie zło, w tym i za choroby współczesnych mu społeczeństw, będzie cywilizacja. Cywilizacyjną sztuczność, osłabienie i delikatność przeciwstawia on naturze utożsamianej z czystością i prawdą. Zagadnienia higieny i tężyzny odnoszą nas tym samym do refleksji o charakterze etycznym czy wręcz aksjologicznym. Normatywizowane postawy względem własnego ciała mają owocować przyjmowaniem określonych postaw względem własnej duszy. Rzecz jasna, jak podkreśla G. Vigarello, idea zimnych kąpieli nie została nigdy przyswojona przez burżuazję, stąd postrzegać ją należy jako jedynie pewien typ idealny czy wręcz utopię, jednak niewątpliwie odegrała ona znaczącą rolę w publicystyce i pedagogice dziewiętnastowiecznej. Czystość i brud wkomponowane zostają w odwieczną procedurę nazywania i zarazem tworzenia, bo przecież „nazywać - to przypisywać reprezentacji reprezentację słowną i zarazem wpisywać ją w tablicę powszechników” (Foucault 2000: 163). Poszczególne wzorce zachowań względem swojego ciała upowszechniają się i wreszcie stają się czymś naturalnym, do momentu nowej definicji i stworzenia nowej reprezentacji. W lekturze Historii brudu i czystości nieustannie staje przed naszymi oczami „nieunikniona historyczność ludzkiej myśli” (Berger i Luckmann 2010: 13).

Niestety współczesne postrzeganie brudu nie pozwala przygotować równie dobrej, co w wiekach wcześniejszych - choć może i utopijnej - recepty na radzenie sobie z nim. Rozwój 
nauki i technologii doprowadził do takiego pesymistycznego stanu, w którym człowiek coraz mocniej zdaje sobie sprawę, że zewsząd otaczają go zagrażające jego życiu lub zdrowiu substancje, istoty, drobnoustroje, czyli - jak nazywa je autor Historii czystości i brudu „niewidzialne potwory”. Z pozoru najczystsza woda może być skażona i zagrażać naszemu życiu, a z pozoru najbielsza skóra może przenosić groźne choroby. Cały świat - konstatuje G. Vigarello - jest podejrzany, jego zdezynfekowanie w całości byłoby niemożliwe. Widać w tym przejawy współczesnego katastrofizmu, który przeniesiony zostaje w obszar najbliższy człowiekowi: obszar jego własnego ciała. Wyłania się więc nowy ideał czystości: aseptyczność, „czystość niewidoczna”, „czystość ukryta” - trzeba więc usunąć ze swego ciała wszelkie możliwe grzyby, bakterie, pierwotniaki i wirusy, żeby być naprawdę czystym. Gdyby dalej iść tropem śladów pozostawionych przez Foucaulta, należałoby postawić pytanie o to, kto w ramach tego nowego pola epistemologicznego zdobywa największą władzę nad człowiekiem. Okazałoby się, że naukowcy, lekarze, farmaceuci, genetycy i biotechnolodzy - wszyscy ci, którzy umieją dostrzec to, co gołym okiem nie do dostrzeżenia. Czystość przeniesiona została do gabinetów lekarskich i laboratoriów, a nasza czystość in praxi obudowała się tysiącami specyfików: tabletek, maści, żelów, szamponów, suplementów diety, czopków i pomad. Oprócz tego - jak mówi G. Vigarello - troska o czystość ciał wymusza podejmowanie określonych działań w przestrzeni publicznej, które uczynią ją - choćby nawet z pozoru - bardziej sterylną. Historia czystości i brudu pozwala otworzyć oczy współczesnemu człowiekowi na pewne rzekome oczywistości, które jednak okazują się wyłącznie współczesnymi fenomenami, niejednokrotnie radykalnie odbiegającymi od wcześniejszych formacji postrzeżeniowych. Autor bierze na siebie rolę historyka, który „reprezentuje zorganizowaną pamięć rodzaju ludzkiego” (Mills 2007: 234) i chociaż zdaje sobie sprawę, że ,pamięć owa, podobnie jak historia pisana, jest nad wyraz plastyczna. Zmienia się ona, często dość drastycznie, od jednego pokolenia historyków do drugiego" (Mills 2007: 234), to jednak sama świadomość istnienia takiego mechanizmu chroni go przed popełnieniem błędów generalizacji i buńczucznym przekonaniem, że wykład, którego udziela czytelnikowi, jest wykładem skończonym. Przedstawienie historycznych sposobów postrzegania czystości i brudu to niewątpliwie jeden ze sposobów ludzkiego i społecznego dostrzeżenia upływu czasu (zob. Debord 2009: 116). Dlatego właśnie studium Vigarella należy czytać jako dzieło o charakterze historycznym, socjologicznym, ale także antropologicznym.

\section{BIBLIOGRAFIA}

Berger, Peter L. i Thomas Luckmann. 2010. Spoleczne tworzenie rzeczywistości. Traktat z socjologii wiedzy, przeł. J. Niżnik, Warszawa: Wydawnictwo Naukowe PWN.

Foucault, Michel. 1977. Archeologia wiedzy, przeł. A. Siemek, Warszawa: Państwowy Instytut Wydawniczy.

Foucault, Michel. 1987. Historia szaleństwa w dobie klasycyzmu, przeł. H. Kęszycka, Warszawa: Państwowy Instytut Wydawniczy.

Foucault, Michel. 2000. Słowa i rzeczy. Archeologia nauk humanistycznych, przeł. T. Komendant, Gdańsk: Słowo/Obraz Terytoria. 
Foucault, Michel. 2009. Nadzorować i karać: narodziny więzienia, przeł. T. Komendant, Warszawa: Wydawnictwo Aletheia.

Foucault, Michel. 2010. Historia seksualności, przeł. B. Banasiak, T. Komendant i K. Matuszewski, Gdańsk: Słowo/Obraz Terytoria.

Macherey, Pierre. 2011. Siła norm. Od Canguilhema do Foucaulta, przeł. A. Czarnacka, Warszawa: Instytut Wydawniczy Książka i Prasa.

Mills, Charles Wright. 2007. Wyobraźnia socjologiczna, przeł. M. Bucholc, Warszawa: Wydawnictwo Naukowe PWN.

Walzer, Michael. 2012. Moralne maksimum, moralne minimum, przeł. J. Erbel, Warszawa: Wydawnictwo Krytyki Politycznej. 